\title{
РЕЦЦЕНЗІї
}

УДК 821.161.2.09

\author{
Бровко Олена, \\ Київський університет імені Бориса Грінченка (Київ, Україна) \\ ORCID ID 0000-0001-7519-4725 \\ e-mail: o.brovko@kubg.edu.ua
}

https://doi.org/10.28925/2412-2475.2021.17.10

\section{ІНТЕРМЕДІАЛЬНЕ ПРОЧИТАННЯ УКРАЇНСЬКОЇ ЛІТЕРАТУРИ}

(Рецензія: Горболіс Л.М. Міжмистецькі контакти українського тексту. Суми: Вид-во СумДПу імені А.С. Макаренка, 2021. 312 с.)

Упродовж останнього десятиліття теорія інтермедіальності збагатилася різноаспектними студіями в галузі гуманітарних наук, культури й мистецтва. Увійшовши до наукового обігу філософів, культурологів, мистецтвознавців, істориків і теоретиків літератури, дефініція «інтермедіальність» інспірувала низку розвідок, присвячених взаємодії і синтезу різних видів мистецтва, кореляції інтермедіальності й інтерсеміотичності, інтермедіальності й інтертекстуальності.

Назва «Міжмистецькі контакти українського тексту» на тлі вишуканих ілюстрацій французького художника Роже Сюро (Roger Suraud) $\epsilon$ влучним антиципаційним прийомом, що анонсує змістові домінанти нової монографії Лариси Горболіс.

Літературознавиця подає огляд актуальних досліджень Дмитра Наливайка, Віри Просалової, Лесі Генералюк, Тетяни Бовсунівської, Миколи Ільницького, Григорія Клочека, Галини Сиваченко, Олексія Тимашкова, Наталії Морченюк, Еліни Циховської, Олександра Брайка, Світлани Маценки та інших науковців, намагаючись розібратися в сучасному «інтермедіальному бумі» (Галина Левченко). З’ясувати специфіку міжмистецької взаємодії намагалася і авторка цієї рецензї в попередніх публікаціях, звернувши увагу на те, що традиційно інтерме- діальність постає як особлива актуальна форма діалогу культур засобами взаємодії художніх референцій (образів і стилістичних прийомів, які мають знаковий характер для певної епохи); iii трактують як наявність у літературному тексті образних структур, що несуть інформацію про естетичні можливості інших видів мистецтва (Бровко, 2013, с. 36). У ширшому смислі, за твердженням Наталії Тишуніної, інтермедіальність сприймається як створення цілісного поліхудожнього простору в системі культури або створення художньої «метамови» культури; особливості рецепції специфічного типу внутрішніх текстових зв'язків у художньому творі, заснованих на взаємозв'язках мови різних видів мистецтв; специфічна методологія аналізу як окремого тексту, так і художньої культури загалом; методологічний принцип, актуальний для міждисциплінарних студій (Тишуніна, 2001, с. 149-154).

Лариса Горболіс обгрунтовано обирає розуміння інтермедіальності як універсального художнього принципу, авторської та читацької стратегії взаємодії різних мистецьких дискурсів, окреслення їхніх кордонів, помежів'я і взаємопроникнення, адже іï мета полягає у виявленні та дослідженні «в обраних для аналізу творах українських письменників <..> особливості художнього освоєння міжмистецьких зв'язків 
(літератури й музики, малярства, кіно, театру, хореографіï) на різних рівнях організації тексту» (Горболіс, 2021, с. 5). На домінування естетико-рецептивного підходу вказує й епіграф до монографії: «Краса лежить не в матеріалі, що служить їй основою, не в моделях, а в тім, яке враження робить на нас даний твір і якими способами артист зумів осягнути те враження» (Іван Франко «Із секретів поетичної творчості»).

Запропоновані Ларисою Горболіс матеріали - це передусім «авторське прочитання показових в українському письменстві творів, акцент (із застосуванням міжмистецької складової) на специфічних рисах творчої манери письменників, своєрідності їхнього доробку на тлі стильових змагань доби» (Горболіс, 2021 , с. 49). Заслуговує на схвалення апеляція до особистого досвіду авторки як кваліфікованої читачки, адже ï фахові спостереження зумовлюють оригінальні інтерпретаційні моделі й окреслюють напрямки подальших студій. Зокрема, переконливими $є$ висновки щодо естетики музичного супроводу до кінотексту Олександра Довженка, створеного сучасним українським етнохаос гуртом «ДахаБраха», в розділі «Література - кіно».

Рецепцію п’єси Павла Ар’є «На початку і наприкінці часів» Лариса Горболіс пов'язує 3 власним досвідом театрального глядача вистави «Баба Пріся» Львівського театру імені Лесі Українки (режисер - Олексій Кравчук) (розділ «Література - театр»). Альбом Юрія Іздрика «UNDERWORD» як технологічний мультимистецький синтез текстів, колажів і світлини окреслює, за словами авторки монографії, перспективу «зануритися у широкоформатну матрицю доробку письменника, заглибитися у його складомислення, світо- і саморозуміння» (Горболіс, 2021, с. 23). Увага до технічних засобів залучення широкої аудиторії реципієнтів у романі Макса Кідрука «Доки світло не згасне назавжди» окреслює перспективи наукового висвітлення таких літературних практик із інтермедіальних позицій, у тому числі в контексті осмислення доповненої реальності.

Глибиною аналізу тексту вирізняється розділ «Література - хореографія», в якому науковиця зосереджується на новелістиці відомого митця межі XIX-XX ст. Михайла Яцкова і сучасного письменника, музикознавця, хореографа Володимира Корнійчука.

Також особливий науковий інтерес становить аналіз текстів літератури факту і фікційних творів в аспекті міжмистецької взаємодії на засадах інтеграції різних методологічних підходів. У цьому ракурсі актуальністю й новизною вирізняється матеріал дослідження, обраний для аналізу і теоретичних узагальнень у розділах «Література - музика», «Література - малярство», а саме: роман «Прилетіла ластівочка» Ірен Роздобудько, присвячений Миколі Леонтовичу, повість-феєрія Лесі Білик «Промені й тіні Кароля Ліпінського», повість Тетяни Сидоренко «Ольга, дружина Пікассо», де літературознавиця не тільки розкриває оригінальні моделі українських екфразисів, а й увиразнює специфіку сучасної художньої біографістики, занурюється в моделювання метатексту, наголошує на культурологічних домінантах цих творів, а також виокремлює складники літературної топографії (наприклад, Львів як простір творчої реалізації Кароля Ліпінського) (Горболіс, 2021, с. 157-160).

Проте не з усіма авторськими інтерпретаціями можна погодитися. Зокрема, дискусійною $є$ пропозиція вивчення кінематографічного потенціалу новели «Камінний хрест» Василя Стефаника через асоціації з полотнами та скульптурними роботами Сальвадора Далі. Зважаючи на максимальну напругу художнього вираження в текстах Василя Стефаника («...аж пальці мені викручувались з болю й я гриз їх, аж мене це моє сиве волосся коштувало. І все, що я писав, мене боліло» (Стефаник, 1971, c. 15)), екзистенційне злиття людини з природою у згаданій новелі, на нашу думку, все-таки більш мотивованим є увиразнення зв'язку з експресіоністичним живописом.

В окремих підрозділах монографії дослідниця поглиблює ідеї, доповнює новими аргументами тези, оприлюднені у попередніх публікаціях, коректно покликаючись на них у списку використаних джерел. На жаль, у цьому списку немає зазначеної у примітках розвідки Лариси Горболіс, присвяченої мистецькому діалогу лірики Богдана-Ігоря Антонича й живопису Маpiї Приймаченко (Горболіс, 2012), актуалізованої в ракурсі новітніх дослідницьких пошуків. Запропонована Ларисою Горболіс інтерпретаційна модель, на наше переконання, стане доброю основою для подальших студій.

Монографія вирізняється тим, що в аналізованих текстах уважна літературознавиця виокремлює цікаві дослідницькі вектори, певною мірою суголосні естетиці Роже Сюро, чия багатошарова музика живопису прикрашає обкладинку цієї книжки, що неодмінно буде оцінена зацікавленими читачами. 


\section{ДЖЕРЕЛА}

1. Бровко, О. (2013). Сучасні версії українського роману в новелах: інтермедіальний вимір. Літературний процес: методологія, імена, тенденціï, 2, 36-38.

2. Горболіс, Л. (2012). Суголосність художніх світів закоханих у життя українців: порівняльний аспект творів Богдана-Ігоря Антонича і Марії Приймаченко. Дивослово: Українська мова й література в навчальних закладах, 8, 56-61.

3. Горболіс, Л. (2021). Міжмистецьькі контакти украӥнського тексту. Вид-во СумДПУ імені А.С. Макаренка.

4. Стефаник, В. (1971). Твори. Дніпро.

5. Тишунина, В. (2001). Методология интермедиального анализа в свете междисциплинарных исследований. Методология гуманитарного знания в перспективе ХХІ века. К 80-летию профессора Моисея Самойловича Кагана: материаль Международной научной конференции 18 мая 2001 г., Санкт-Петербург. философ. об-во.

\section{REFERENCES}

1. Brovko, O. (2013). Suchasni versii Ukrainskoho romanu v novelakh: intermedyalnyi vymir [Modern Versions of the Ukrainian Novel in Novels: intermedial dimension] Literaturnyi Protses: Metodolohiia. Imena. Tendentsii, 2, 36-38 [in Ukrainian].

2. Horbolis, L. (2012). Suholosnist khudozhnikh svitiv zakokhanykh u zhyttia ukraintsiv: porivnialnyi aspekt tvoriv Bohdana-Ihoria Antonycha i Marii Pryimachenko [The Harmony of the Art Worlds of Ukrainians in Love: a comparative aspect of the works of Bohdan-Ihor Antonych and Maria Pryimachenko]. Dyvoslovo: Ukrainska mova i literatura v navchalnykh zakladakh, 8, 56-59 [in Ukrainian].

3. Horbolis, L. (2021). Mizhmystetski kontakty Ukrainskoho tekstu [Inter-Artistic Contacts of the Ukrainian Text]. Sumy, Vyd-vo SumDPU imeni A. S. Makarenka [in Ukrainian].

4. Stefanyk, V. (1971). Tvory [Works]. Dnipro [in Ukrainian].

5. Tishunina, N. V. (2001). Metodolologiia intermedialnogo analiza v svete mezhdistsiplinarnykh issledovanii [Methodology of Intermedial Analysis in the View of Interdisciplinary Research]. Metodologiia gumanitarnogo znaniia v perspektive XXI veka. K 80-letiiu professora Moiseia Samoilovicha Kagana. Materialy Mezhdunarodnoi nauchnoi konferentsii 18 maia 2001 g. Sankt-Peterburg. filosof. o-vo [in Russian].

\section{Brovko Olena,}

Borys Grinchenko Kyiv University (Kyiv, Ukraine)

ORCID ID 0000-0001-7519-4725

e-mail: o.brovko@kubg.edu.ua

\section{INTERMEDIATE READING OF UKRAINIAN LITERATURE}

Стаття надійшла до редакції 02.05.2021

Прийнято до друку 14.05.2021 